\title{
Introducing Bibliotherapy in Public Libraries of Jaffna district: an Exploratory Study
}

Arulanantham, $\mathrm{S}^{1}$. and Navaneethakrishnan, $\mathrm{S}^{2}$.

\begin{abstract}
This study investigates the role of the public library sector of Jaffna district in Northern Sri Lanka towards providing bibliotherapy as a service to the waraffected people seeking help in solving their problems. Using Survey research method, collected data was analyzed to find out the awareness of the concept, acceptance of bibliotherapy as method of treatment, existence and suitability of bibliotherapy in public libraries and the attitude of the librarians to be a bibliotherapist. The study suggests the possibility of implementing bibliotherapy in public libraries of Jaffna district with the support of health authorities.
\end{abstract}

Keywords: Bibliotherapy, Bibliotherapy-Public libraries, Bibliotherapy - Library services, Reading therapy

\section{Introduction}

Reconstructing a post-war society soon after a longstanding civil war and the corresponding efforts of rehabilitation of its members from the physical and emotional damages demand a high intensity of services in every sphere. In the administrative district of Jaffna in northern Sri Lanka where a considerable portion of the population, badly affected by a long drawn war, is in great need of all forms of treatment including therapy and counseling to mental illness. The total number of the mentally affected is extremely high in proportion compared to those in a normal society. Bringing the affected back to normal way of life is a tremendous task faced by the other members of the society. In a situation in which every member of the society is expected to play a positive role, librarians and library professionals are too expected to define their roles towards the

\footnotetext{
Corresponding Author:

${ }^{1}$ Librarian, University of Jaffna, Sri Lanka. Email:sriarul91@gmail.com

${ }^{2}$ Assistant Librarian, University of Jaffna, Sri Lanka. Email:ksnavan@yahoo.com
} 
reconstruction of a fractured society. Public libraries and reading rooms with their stock of knowledge and information can also become service points of therapy to affected people by applying the methods of bibliotherapy.

Bibliotherapy refers simply to the use of reading materials for help in solving personal problems or for psychiatric therapy. Bibliotherapy is considered as a service offering solace to affected souls. The basic concept behind bibliotherapy is that reading is a healing experience. Literary sources can assist with the resolution of complex problems (Sullivan \& Strang, 2002)

\section{Jaffna District: an overview}

The majority of the population living in the areas of the Northern region of Sri Lanka belongs to Tamil speaking minority community. The region comprises of 05 administrative districts, such as Jaffna, Kilinochchi, Mannar, Mullaitivu and Vavuniya. Among them, Jaffna district is the largest by population $(622,589)$, but the smallest by land area $(1,023$ square $\mathrm{km})$. Jaffna district is divided into 14 sub divisions. For the last two decades until May 2009, the long drawn war had caused severe impediment to the economic and infrastructure development, and the population of the area was subjected to series of heavy material and emotional losses and as a result, severely traumatized.

\section{Origins of Bibliotherapy}

The relationship between bibliotherapy and libraries is as old as ancient civilization itself. Around 300 B.C., an inscription was found on a library in Alexandria which read, "The nourishment of the soul" (Afolayan, 1992). Shera gives a note that Diororus of Sicilly, in inscribing the monuments at Thebes, mentions a library over the portal of which was inscribed, "Medicine for the Soul" (Shera, 1976). There was a belief in the healing power of books and the value of books as a source for improving the quality of life (Pardeck, 1993). In 1939 bibliotherapy received official library recognition when the Hospital 
Division of the American Library Association appointed its first bibliotherapy committee. In addition, as early as the 1800s, Dr. Benjamin Rush recommended the Bible as therapeutic reading. Benjamin Rush and John Minsion Galt II were considered as Pioneers of Bibliotherapy in America and reading was considered as one of the major therapeutic measures in treating mental patients and by the middle of the $19^{\text {th }}$ century every major mental hospital has a patient library (Weimerskirch, 1965).

\section{Defining Bibliotherapy}

Bibliotherapy as a term coined by Samuel Crothers in 1916 is deriving from two Greek words biblio meaning "book" and therapia meaning "healing" and refers simply to "the use of reading materials for help in solving personal problems or for psychiatric therapy." Crothers asserts that qualified reading will develop new knowledge and ideas for life, and it soon results in a healing process that can enrich the readers' personality (Crothers, 1916). Reitz defines that the use of books selected on the basis of content in a planned reading program designed to facilitate the recovery of patients suffering from mental illness or emotional disturbance (Reitz, 2006). The first written definition was published in Dorland's Illustrated Medical Dictionary in 1941, and defines bibliotherapy as "the employment of books and the reading of them in the treatment of nervous disease". Webster defines bibliotherapy as "the use of reading materials for help in solving personal problems or for psychiatric therapy; also guidance in the solution of personal problems through directed reading.

In the past, bibliotherapy was only used for patients in mental hospitals and for people that were seriously ill, although today it has widespread use. Many educators and adults have resorted to bibliotherapy to help individuals and groups deal with normal and emotional problems they encounter with (Rubin, 1978). 


\section{Current Trends in Bibliotherapy}

Community use of bibliotherapy is the trend for the future. Its effectiveness, its economy, its very attractiveness must be demonstrated widely if it is to gain the recognition and acceptance of administrators and of the medical and allied professions (Hannigan, 1962). Due to the proliferation of settings for bibliotherapy, as well as the growing use of media other than books, new methods of practice and preparation are always being developed (Rubin, 1979). In USA a national survey of "Bibliotherapy Practices in Counselling" was conducted in 2008 (Pehrsson \& McMillen, 2010).

\section{Need of the Study}

The post war period gave a breathing space for the people to relieve their distress and mental pain in various ways such as psychotherapeutic and psychiatric interventions. But the limited availability of resources and deteriorating social and security situation in the area make the treatment a difficult task.

Northern regional office of the health services took some initial steps to improve the health condition of Jaffna people. A plan to create a space for the clients to spend their leisure time was in progress. Voluntary organizations are agreed to support this endeavour.

As it was felt this is the opportune time for the library professionals to study the growing trend of the therapeutic role of the library, this study was carried out in Jaffna district with the aim of fulfilling the purpose.

\section{Objectives of the Study}

The main objective of this research study is to identify and investigate the attitude of public libraries, library professionals and administrators of local government authority of 
Jaffna district towards providing bibliotherapy as one of their services. Also it tries to identify the growing trend of the people seeking help in solving their personal problems or for psychiatric therapy in this district. The responsibility for establishing bibliotherapy as an accepted, vital part of treatment of the affected obviously rests squarely with librarians themselves.

\section{Significance of the Study}

We are living in an age when the concepts of treatment, care, and rehabilitation of people are based upon the idea of a team working together with one goal, the cure of the people. The primary function of the librarian on the therapy team, as in other areas of library service, is based upon cognizance of the needs of the community and of the individual reader and upon knowledge of books available to meet those needs. In carrying out the functions of bibliotherapy, the librarian in consultation with the medical staff and as part of the total medical program, stimulates and develops reading interests. The librarian recommends and provides reading materials as well.

The responsibility for establishing bibliotherapy as an accepted, vital part of treatment of the affected obviously rests squarely with librarians themselves. If we really believe what we say we do about the beneficial effects of bibliotherapy, then we must make sure that bibliotherapy service is generally available. Its effectiveness, its economy, its very attractiveness must be demonstrated widely if it is to gain the recognition and acceptance of administrators and of the medical and allied professionals. The librarian needs to know the purposes and objectives of other professional groups such as nurses, social workers, occupational therapists, psychologists, psychiatrists, and others-whose work is integrated into the overall plan of treatment (_Hannigan, 1962).

\section{Partnership between Public Libraries and Health Services}

Reading has long been understood to provide therapeutic benefits. Recreational reading for pleasure and relaxation provides emotional strength and stability by allowing people 
to take time out from their day to day lives, while targeted self-directed reading allows people to find a sense of control or well-being by directly addressing issues that they may be facing, either in their day to day lives or in times of crisis. Healthcare providers have been identified as a community sector that is well-positioned to aid public libraries in promoting the benefits of reading - as Healthcare Services provide access to a wider public than simply a pre-existing library customer base. Such a partnership would provide public libraries with the opportunity to reach out to non-library users in their local communities and encourage them to pursue reading as a form of beneficial self-help or therapy, while also providing a continued reminder to current library users of the benefits of reading. With the aid of Healthcare providers, public libraries are well positioned to provide both individual reading programs and book discussion groups that will allow libraries to make a major contribution not only to Jaffna, but also to improving the nation's health and wellbeing.

\section{Literature Review and Methodology}

Beatty gives a chronological picture of several historical reviews and bibliographies about bibliotherapy appeared during the first half of $20^{\text {th }}$ century (Beatty, 1962). In 1904, bibliotherapy was first accepted as an aspect of librarianship, when a trained librarian became administrator of libraries at Mclean Hospital at Waverly, Massachusetts. The use of books, assumed a leading role as therapy. In the 1920s, Sadie Peterson-Delaney, a librarian of the Veterans' Hospital in Tuskegee, Alabama, had an outstanding bibliotherapy program that used books to treat the psychological and physical needs of AfricanAmerican war veterans. Her method received worldwide recognition (Brown, 1975). The first article written by a librarian about bibliotherapy was in 1919 . The librarian was coauthor with a neurologist in the publication of "The therapeutic use of hospital library" (Bibliotherapy sourcebook, 1978).

The October 1962 issue of Library Trends was devoted to bibliotherapy, and included papers written by researchers in the fields of nursing, psychology, psychiatry, and 
librarianship. In this issue Kinney suggested a bibliotherapy program at Library Schools, one which should be on the graduate level and include courses, experience working in a library, a broad knowledge of literature, and a study of psychology, and elementary psychiatry. Additionally, it should include training in statistics, report writing, and group dynamic.( Kinney,1962)

In 1971, another two distinguished contributions to bibliotherapy literature appeared. "Bibliotherapy Methods and Materials" produced by both the Bibliotherapy Committee and the Committee on the Troubled Child (ALA Committees), and "Reading Guidance and Bibliotherapy in Public, Hospital and Institution Libraries" which was issued by the Library School of the University of Wisconsin. In 1991 Alice Smith published the most distinguished study on teaching bibliotherapy in Schools of Library and Information Science (Smith, 1991). She analyzed a random sample of fifteen library school catalogs (1988-1989) searching for courses adaptable for bibliotherapy.

Many studies have been conducted on the positive and negative effects of bibliothearpy. Some researchers disagree on some of these issues and therefore there are mixed results on findings in these areas. Overall the use of bibliotherapy continues to increase, especially in schools, to help people cope with problems or learn how to face situations that may arise in their lives (Schrank et al., 1981).

\section{Methods and Materials}

The current study employed both descriptive and survey research methods. It was identified through the descriptive analysis of the various statistics, more than 44,603 (7\% of the total population) people seeking for help in solving personal problems or for psychiatric therapy (Statistical Hand Book of RDHS, 2010). Table 1 indicates that there are 2629 diagnosed Psychiatric patients and 304 affected by gender based violence. 
Table 01. Categories of population seeking for help by divisional secretariat

\begin{tabular}{|c|c|c|c|c|c|c|c|c|c|c|}
\hline Name of the divisional secretariat & 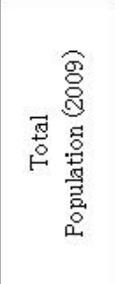 & 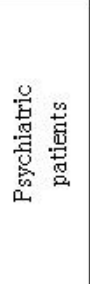 & 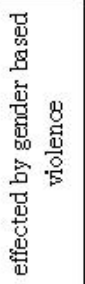 & 电 & 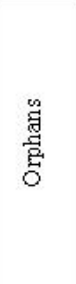 & 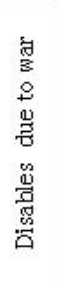 & 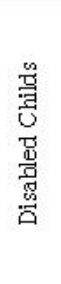 & 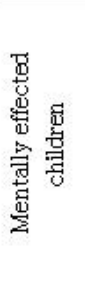 & 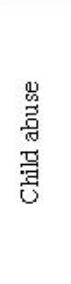 & 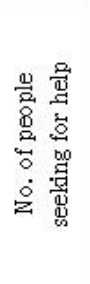 \\
\hline Delft & 4,873 & 9 & 0 & 215 & 53 & 2 & 9 & 2 & 11 & 301 \\
\hline Islands South (Velanai) & 18,983 & 12 & 14 & 807 & 353 & 18 & 46 & 6 & 30 & 1286 \\
\hline Karainagar & 10,729 & 9 & 9 & 639 & 260 & 2 & 21 & 2 & 38 & 980 \\
\hline Islands North (Kayts) & 16,122 & 13 & 11 & 739 & 214 & 0 & 10 & 0 & 6 & 993 \\
\hline Jaffina & 55,469 & 516 & 38 & 2087 & 901 & 47 & 130 & 92 & 252 & 4,063 \\
\hline Nallur & 66,487 & 0 & 26 & 3659 & 853 & 31 & 38 & 28 & 84 & 4,719 \\
\hline Valikamam South - West (Sandilipay) & 61,922 & 29 & 32 & 2275 & 80 & 18 & 78 & 35 & 95 & 2,642 \\
\hline Valikamam West (Chankanai) & 50,886 & 7 & 42 & 2603 & 813 & 12 & 36 & 22 & 92 & 3,627 \\
\hline Valikamam South (Uduvil) & 53,824 & 0 & 21 & 2538 & 72 & 12 & 36 & 9 & 22 & 2,710 \\
\hline Valikamam North (Tellippalai) & 26,974 & 1093 & 11 & 1128 & 512 & 25 & 205 & 18 & 336 & 3,328 \\
\hline Valikamam East (Kopay) & 77,652 & 242 & 45 & 3763 & 1325 & 29 & 146 & 36 & 139 & 5,725 \\
\hline Thenmarachchi (Chavakachcheri) & 70,887 & 78 & 22 & 3408 & 3134 & 1 & 61 & 37 & 7 & 6,748 \\
\hline Vadamarachchi South-West (Karaveddy) & 48,169 & 0 & 18 & 2656 & 612 & 0 & 77 & 28 & 9 & 3,400 \\
\hline Vadamarachchi North (Point Pedro) & 53,517 & 621 & 13 & 2649 & 162 & 8 & 48 & 13 & 36 & 3,550 \\
\hline Vadamarachchi East (Muruthankerney) & 6,095 & 0 & 2 & 281 & 227 & 2 & 18 & 1 & 0 & 531 \\
\hline Total & 622,589 & 2629 & 304 & 29447 & 9571 & 207 & 959 & 329 & 1157 & 44,603 \\
\hline
\end{tabular}

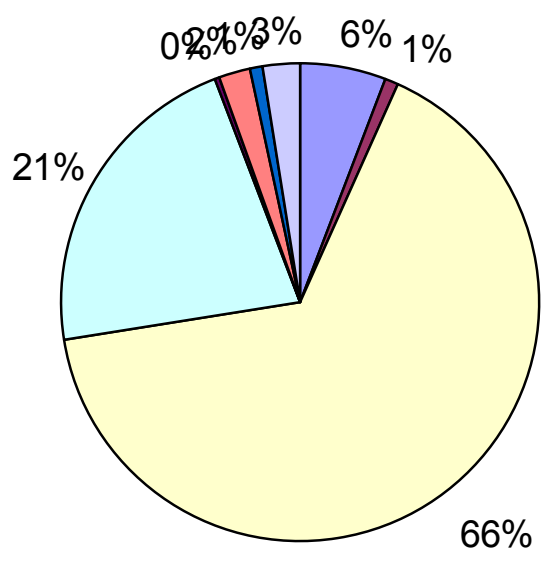

$\square$ Psychiatric patients

$\square$ Gender based violence

$\square$ Widows

$\square$ Orphans

$\square$ disable

$\square$ disabled child

$\square$ mentally affected

$\square$ child abuse

\section{Figure 1: Population seeking for help}




\section{Data Collection Method}

In survey method a questionnaire was designed to elicit information concerning reasons and reflection on this topic from a random sample of administrators and professionals related to Public libraries in Jaffna. $(n=53)$. Table 2 provides the number of public libraries in Jaffna District (Statistical Information, 2013).

Table 2 : Number of Public Libraries in Jaffna District

\begin{tabular}{|l|l|l|l|}
\hline Name & No. & Name & No \\
\hline Municipal Council & & Pradesiya sabas & \\
\hline Jaffna & 6 & Nallur & 3 \\
\hline Urban Councils & & Valigamam South West & 4 \\
\hline Chavakachcheri & 3 & Valigamam West & 4 \\
\hline Point Pedro & 1 & Valigamam South & 3 \\
\hline Valvetithurai & 1 & Valigamam North & 4 \\
\hline Pradesiya sabas & & Valigamam East & 5 \\
\hline Delf & 2 & Vadamaradchi South west & 4 \\
\hline Island south & 5 & Chavakachceri & 6 \\
\hline Island North & 4 & Point Pedro & 3 \\
\hline Karai Nagar & 2 & & \\
\hline Total & & 60 & \\
\hline
\end{tabular}

Using the statistical technique, the data was analyzed to find out the awareness, acceptance, existence, and suitability of bibliotherapy and the Characteristics of the librarian as bibliotherapist. 


\section{Results and Discussions}

Library professionals working in the public libraries and the administrators responsible for the public libraries in Jaffna district were selected in the sample using random sampling technique. Ten of the fifty three participants are administrators of public libraries while rest is working as librarians.

\section{Awareness of the Concept}

First part of the questionnaire mainly focused on assessing the knowledge of the participants on bibliotherapy. It consists of questions relating to the basic knowledge about bibliotherapy, how the awareness of the nature of the diseases and their therapeutical aspects could be achieved by developing a reading habit and how the habit of reading could be used as counselling. Majority $(96.2 \%)$ responded to this section, most of them (94\%) have awareness of the concept of bibliotherapy even though they were not familiar with the term bibliotherapy. All the participants agreed that the awareness about various diseases can be gained through reading and having the opinion that reading can be used to cure certain diseases/illness too. When the participants were asked whether reading could specifically cure mental illness in particular, all responded to this question and $98.1 \%$ responded positively. $96.2 \%$ of the participants fully agreed that reading can be a source of mental strength to mentally affected and alternately-abled children and reading could be used as a method of counseling.

\section{Table-3: Awareness of the Concept Bibliotherapy}

\begin{tabular}{|l|c|}
\hline Details & Response (\%) \\
\hline Awareness of the concept & 94 \\
\hline Awareness about various diseases & 91.5 \\
\hline Reading can be used to cure certain diseases & 96.2 \\
\hline Reading is a source of mental strength & 96.2 \\
\hline
\end{tabular}




\section{Transforming Library in to Provider of Bibliotherapy}

Second part of the questionnaire was designed to find out the opinion of the participants about transforming a library into a provider of bibliotherapy. There were five questions relating to this section

1. Proposing bibliotherapy as sub objective of a library

2. Proposing bibliotherapy as a section of a library

3. Introducing bibliotherapy as a service to the people affected by war

4. Building a collection in the library with the aim of implementing bibliotherapy

5. Developing manpower resources with the aim of providing bibliotherapy

$95.8 \%$ of the participants responded to this section. Nearly half of the total respondents fully agreed to organize a bibliotherapic unit within the library setup while $41 \%$ partially agreed for this proposal. Only $1.9 \%$ responded negatively. Majority of the respondents (98.1\%) were in favour of introducing bibliotherapy as one of the services in their libraries. Majority (90.1\%) responded positively to the question relating to building up a collection with the aim of implementing bibliotherapy.

\section{Suitability of Resources}

Third part of the questionnaire was designed to find out the opinion of the participants regarding the internal and external environmental factors influencing the introduction of this service. Table 3 lists the factors and the type of response received to this section. Majority (85.22\%) were satisfied with the existing resources. Graph -1 indicates the positive response with regard to suitability of resources. 
Table 4: Types of response in suitability of resources

\begin{tabular}{|l|l|l|l|}
\hline Suitability of resources & $\begin{array}{l}\text { Positive } \\
\text { response (\%) }\end{array}$ & $\begin{array}{l}\text { Negative } \\
\text { response }\end{array}$ & $\begin{array}{l}\text { No } \\
\text { response }\end{array}$ \\
\hline $\begin{array}{l}\text { A building with good ventilation, } \\
\text { lighting and safety }\end{array}$ & 83.02 & 15.09 & 1.89 \\
\hline Peaceful and noise free & 88.68 & 9.43 & 1.89 \\
\hline Cleanliness & 90.57 & 7.55 & 1.89 \\
\hline Proper seating facilities & 83.02 & 15.09 & 1.89 \\
\hline Comfortable space & 83.02 & 16.98 & 0.00 \\
\hline Other basic facilities & 83.02 & 16.98 & 0.00 \\
\hline
\end{tabular}

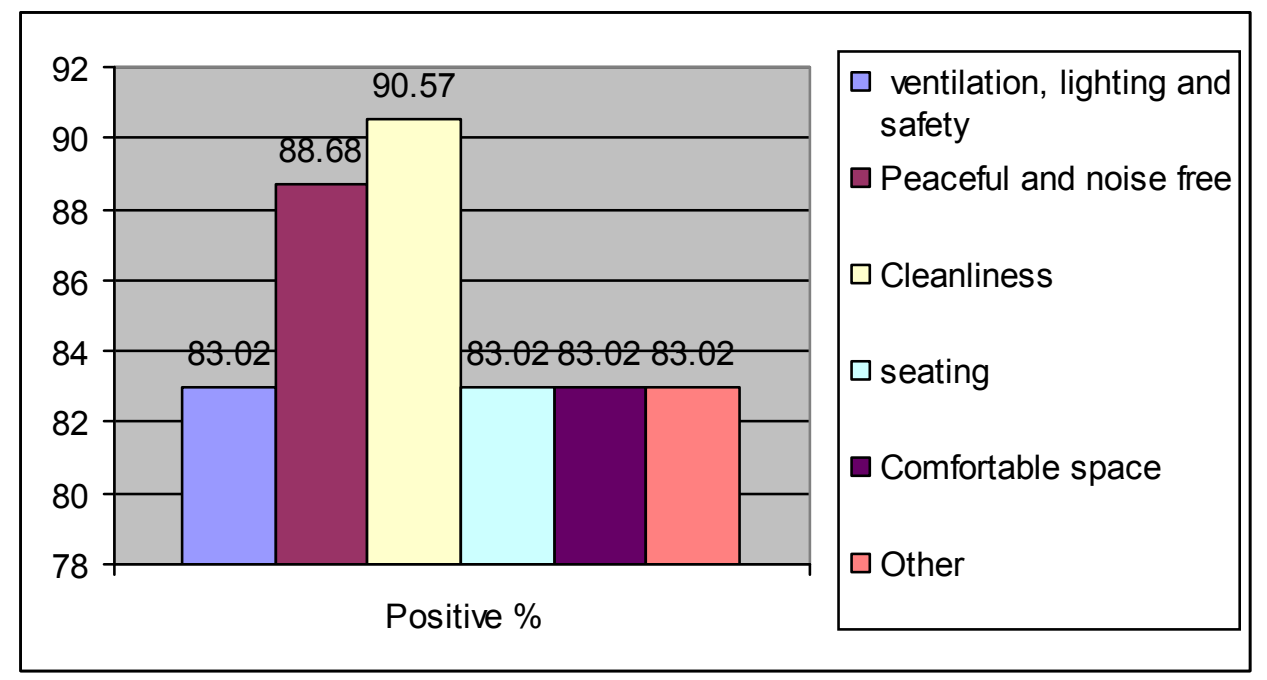

Figure-2 : Positive response about suitability of Resources 


\section{Characteristics of a Librarian as Bibliotherapist}

Fourth part of questionnaire focused on the opinion of the library professionals about the required characteristics of a librarian who is in a position to implement bibliotherapy. The questions of this section also addressed the requirements of co-operation \& proper understanding, positive attitude towards change, efficiency in providing information, instructions with decency, and communicating with respect to human dignity. $97.7 \%$ responded to this section. All the respondents (98.1\%) were in the opinion that a librarian must have cooperation and proper understanding to implement this kind of service. Most of the respondents (96.2\%) agreed that a librarian must have positive attitude towards change, efficiency in providing information, instructions with decency, communicating with respect to human dignity.

\section{Existence of Service Related to "Bibliotherapy"}

Final part of the questionnaire was designed to find out whether public libraries were providing services that could either fully or partially be related to bibliotherapy. Majority (83\%) replied positively. From the opinion of the respondents it is appropriate to note that the public libraries of Jaffna district is implementing variety of services such as book exhibitions or book launches on Children's and Elders' day or disaster day, provision of special facilities for patients and the disabled, organizing training programmes for communication development providing resource materials for counselling centres, and providing mobile library services for orphanages, etc that could more or less be related to the concept of bibiotherapy.

\section{Conclusion and Suggestions}

There is no doubt that public libraries will not stay bibliotherapy-free zones; bibliotherapy will become a part of essential services of public and school libraries, simply because of the continuous and wider growth of bibliotherapy applications. It reflects the strong 
convergence between the goals of bibliotherapy and other library services objectives, such as reader's guidance and reader's advisory.

Introducing bibliotherapy in public libraries could affect positively the stereotype of librarians as well, in that they would enter a new area of communicating with the patrons, the area of healing not only helping, which will open a new job market for graduate students. On the other hand, the bibliotherapy field itself needs to be included in school libraries, as this step will widen its acceptance and applications as a Cognitive psychotherapy approach.

The goal of the developmental bibliotherapy is to promote normal development and selfactualization or to maintain the general mental health level of the society. The study suggests that no better time is there than now to take initiatives to introduce and implement bibliotherapy in libraries. With the support of the Health Department, public libraries are well positioned to provide bibliotherapy programmes that will allow libraries to make a major contribution not only to Jaffna district, but also to the entire nation towards improving the health and wellbeing conditions.

\section{References}

Afolayan, J. A. (1992). Documentary perspective of bibliotherapy in education. Reading Horizons, 33(2), 137

Beatty,W.K.(1962).A historical review of Bibliotherapy. (http://www.ideals.illinois.edu/ bitstream/ handle/2142/6050/ librarytrendsv11i2c_opt.pdf?sequence=1

Rubin, R.J. (1978). Bibliotherapy sourcebook . Arizona: The Oryx Press, pp. xi, 3.

Brown, E. F. (1975). Bibliotherapy and its widening applications. Metuchen: The Scarecrow Press, p. 13.

Crothers, S. (1916). A Literary Clinic. The Atlantic Monthly, 118(3), 291-301.

Pehrsson, D. \& McMillen, P.S. (2010). A National Survey of Bibliotherapy Preparation and Practices of Professional Counsellors. Journal of Creativity in Mental Health, 5(4), 
$412-425$

Hannigan, M.C. (1962). The Librarian in Bibliotherapy: Pharmacist or Bibliotherapist?. Library Trends, 11(192), 184-198

Jaffna District Statistical Hand Book (2010). Jaffna: Statistics branch of District Secretariat Jaffna.

Shera, J.H. (1976). Introduction to Library Science: Basic elements of Library science. Littletone: Libraries unlimited, p14

Kinney, M. M. (1962). The bibliotherapy program: Requirements for training. Library Trends, 11(2), 127-135.

Reitz, J.M. ( 2006). Online Dictionary for Library and Information Science. Retrieved from:http://www.abc-clio.com/ ODLIS/ odlis b.aspx

Pardeck, J.T. \& Pardeck, J. A. (1993). Bibliotherapy: a clinical approach for helping children. Langhorne, Pennsylvania: Gordon and Breach Science Publishers, p. 2.

Rubin, R. J.(1979). Uses of Bibliotherapy in Response to the 1970s. Library Trends, 29(2), 239-252

Schrank, F. A. \& Engels, D.W. (1981). Bibliotherapy as a counseling adjunct: Research findings. The Personal and Guidance Journal, 143-147

Smith, A. G. (1991). Whatever happened to library education for bibliotherapy: A state of the art. Advances in Library Administration and Organization, 9, 34.

Statistical Hand Book of RDHS .(2010). Jaffna: Regional director of Health Services.

Sullivan, A. K. \& Strang, H. R. (2002). Bibliotherapy in the classroom: Using literature to promote the development of emotional intelligence. Childhood Education, 79(2), 74-80.

Weimerskirch, P. J. (1965). Benjamin Rush and John Minsion Galt II: Pioneers of Bibliotherapy in America. Bulletin of Medical Library Association, 53(4), 610-526. 